\title{
TCF 712 Gene Variant Rs7903146 Affects the Risk of Type 2 Diabetes by Modulating Incretin Secretion
}

\author{
Dr. Shanmugapriya Chandrasekaran ${ }^{1 *}$, Dr. Poonguzhali Gopinath ${ }^{2}$, Dr. VAnanthan ${ }^{3}$, \\ Dr. Pragna B.Dolia ${ }^{4}$ \\ ${ }^{1}$ Associate Professor of Biochemistry, Government Medical College-Omandurar Govt. Estate, Triplicane, \\ Chennai \\ ${ }^{2}$ Biochemistry, Government Villupuram Medical College, Mundiyambakkam, Villupuram \\ ${ }^{3}$ Associate Professor of Biochemistry, Government Theni Medical College, Aundipatty, Theni \\ ${ }^{4}$ Dean, ACS Medical College and Hospital, Chennai
}

*Corresponding Author: Dr. Shanmugapriya Chandrasekaran, Associate Professor of Biochemistry, Government Medical College - Omandurar Govt. Estate, Triplicane, Chenna

\begin{abstract}
Type2 diabetes mellitus (T2DM) is a highly inheritable disease. Transcription factor 7-like 2 (TCF7L2) gene regulates the expression of glucagon-like peptide1 (GLP-1) in L cells of small intestine. GLP1 plays a critical role in blood glucose homeostasis by stimulating postprandial insulin secretion and increasing insulin sensitivity. Hence, it is postulated that TCF7L2 gene variants may affect the susceptibility to Type 2 diabetes by altering GLP-1 levels. This case control study was conducted with 90 newly diagnosed patients with Type 2 diabetes mellitus as cases and 90 age and sex matched healthy volunteers as controls. TCF7L2 rs7903146 genotyping was done and we also estimated Fasting and postprandial GLP -1 level, Fasting and Postprandial insulin level and calculated HOMA-IR in both cases and controls. Results showed that T+ genotype, lower fasting GLP-1 level and lower postprandial GLP-1 levels were more observed among cases as compared to controls. Low mean GLP 1 activity, high Mean HOMA-IR, low postprandial insulin, low percentage rise in insulin were observed among $T+$ genotype than among $T$ - genotypic individuals. Hence, the study concludes that T+ genotype causes a decrease in GLP-1 levels, which in turn by decreasing postprandial insulin levels and by increasing insulin resistance increases the risk of Type 2 diabetes.
\end{abstract}

Keywords: Gliptins, GLP-1, Incretins, Polymorphism, Type 2 diabetes, TCF7L2, rs7903146

Abbreviations: TCF7L2 - Transcription Factor 7-Like 2, GLP1 - Glucagon like Peptide , HOMA-IR Homeostatic Model Assessment - Insulin Resistance Index, Wnt - Wingless/Integrated Pathway, MLR Multiple Linear Regression, ANOVA - Analysis of Variance

\section{INTRODUCTION}

Type 2 diabetes is a complex metabolic disorder with both genetic and environmental factors such as food habits and lifestyle contributing to its pathogenesis ${ }^{[1]}$. Due to its complex aetiology, the progress of discovery of genetic components for Type 2 diabetes had been very slow until the advent of high throughput genome-wide association (GWA) studies ${ }^{[2][3]}$. Most individuals with T2DM suffer serious complications of chronic hyperglycemia, involved in nephropathy, neuropathy, retinopathy, and accelerated development of cardiovascular disease. When the micro vascular complications are related to the degree of fasting hyperglycemia ${ }^{[4]}$, macro vascular complication like atherosclerosis is related to postprandial glycemic level ${ }^{[5]}$. One of the regulators of postprandial glucose level is GLP-1.

The importance of gastrointestinal hormones to augment insulin secretion following nutrient ingestion, termed the incretin effect, has generated renewed interest in recent years ${ }^{[6][7][8]}$ of the many putative insulin-stimulatory factors released by the gut, glucagon-like peptide 1 (GLP-1) has received considerable attention because of its potency to lower blood glucose in persons with diabetes and the potential of therapeutics based on the GLP-1 signalling system ${ }^{[7][8]}$. It is produced in the L cells of gut and brain, and it stimulates insulin secretion and lowers blood glucose in both normal subjects and patients with NIDDM ${ }^{[9][10]}$. Remarkably, GLP-1 infusion also lowered blood glucose in patients with 
tissues ${ }^{[14][15][16]}$, actions that would also contribute to lowering blood glucose in vivo. The precursor of GLP-1 is preproglucagon, which is also the precursor of glucagon of $\alpha$ cell of pancreas. In L cells of small intestine, preproglucagon is getting processed to form GLP-1, GLP-2 and glicentin. Tissue specific difference in processing preproglucagon is explained by a tissue specific expression of an enhancer TCF7L2 (Transcription factor 7 - like 2)

Transcription factor 7-like 2 (TCF7L2) gene spans a 215,863 bases region on chromosome 10q25.317 (114700201-114916063, NCBI build $36.2^{[17]}$, and its product is a high-mobility box-containing transcription factor that has a role in activating many genes downstream of the Wnt signalling pathway ${ }^{[18][19][20][21]}$. The bipartite transcription factor, cat/TCF7L2, activates many genes downstream of the Wnt signalling cascade ${ }^{[51]}$. One of the genes transcriptionally regulated by cat/TCF7L2 is proglucagon, which encodes the insulinotropic hormone glucagon- like peptide 1 (GLP-1) ${ }^{[20][21]}$. The tissue specific expression of GLP-1 is explained by the fact that Glycogen synthase $\beta$ binds to TCF7L2 regulator sequence, which is in euchromatin region only in gut cells followed by expression of the transcription factor 7L2 which helps in transcription and processing of preproglucagon to form GLP-1 ${ }^{[22]}$.

There is now growing evidence that, based on the role of TCF7L2 in intestinal cells ${ }^{[22]}$ Grant et al. ${ }^{[23]}$ proposed that variants of TCF7L2 may alter levels of glucagon-like peptide 1, which influences insulin secretion ${ }^{[6][7][8]}$ from the $\beta$ cells of the pancreas or insulin sensitivity ${ }^{[24][25][26]}$. Thus, one hypothesis is that TCF7L2 might influence the risk of Type 2 diabetes by influencing insulin secretion and action, by altering GLP-1 level.

Indeed, several studies have reported reduced insulin secretion after an oral glucose tolerance test (OGTT) in subjects with TCF7L2 variants, using ratios between insulin and glucose levels such as insulinogenic index ${ }^{[24][25][26]}$. Reduced insulin secretion in response to oral compared with intravenous

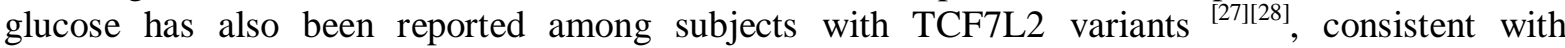
alterations in the incretin system. However, several studies have shown no change in insulin sensitivity ${ }^{[25][27]}$, whereas other studies have shown increased ${ }^{[24][30]}$ or decreased ${ }^{[28][29]}$ insulin sensitivity. The present study was undertaken to clarify the effect of TCF7L2 on insulin secretion and sensitivity and in turn on the risk of Type 2 diabetes.

\section{MATERIALS AND MethodS}

\subsection{Study Population}

\subsubsection{Cases}

The study sample comprised 90 south Indian newly diagnosed Diabetic patients (163 male, 18 female) of mean age $50.34 \pm 9.84$ years.

Inclusion criterion $^{31}$ were,

- Fasting plasma glucose $\geq 126 \mathrm{mg} / \mathrm{dL}$ or

- Postprandial plasma glucose $\geq 200 \mathrm{mg} / \mathrm{dL}$ or

- Random plasma glucose $\geq 200 \mathrm{mg} / \mathrm{dL}$

\subsubsection{Exclusion Criteria}

- Secondary causes of diabetes like hyperthyroidism, acromegaly, pheochromocytoma were excluded

- Known diabetic patients on treatment were excluded to avoid the interference of glucose toxicity with insulin secretion32.

\subsubsection{Control Subjects}

Controls were recruited from people attending the master health check. Age and Sex were matched.

\subsection{Methods}

Height, weight, waist circumference and hip circumference were measured, and blood samples were collected by Venipuncture after overnight fasting in both a plain tube and the tube with sodium fluoride and potassium oxalate. Plain tube was centrifuged at $2000 \mathrm{rpm}$ for 10 minutes and serum was 
aliquoted in two tubes and one was used for estimation of fasting insulin levels and the other for GLP-1 levels into which a DPPIV inhibitor ${ }^{[33]}$ was added. Fluoride and oxalate tubes were centrifuged at $2000 \mathrm{rpm}$ for twenty minutes to get the buffy coat for DNA extraction and the plasma was used for fasting plasma glucose estimation. Post prandial blood samples were collected 2 hours after giving $100 \mathrm{~g}$ of glucose dissolved in $75 \mathrm{~mL}$ of water in plain and sodium fluoride - potassium oxalate tubes. Plain tube was centrifuged at $2000 \mathrm{rpm}$ for 10 minutes and serum was aliquoted in two tubes and one was used for estimation of postprandial insulin and the other for GLP-1 levels into which a DPPIV inhibitor was added. Fluoride, oxalate tube was centrifuged at $2000 \mathrm{rpm}$ for ten minutes and the plasma was used for post prandial plasma glucose estimation.

- Fasting and postprandial plasma glucose was measured by glucose oxidase peroxide method with an auto analyzer (XL 300) and manufacturers Agent kits.

- Fasting and postprandial Insulin were measured using a sandwich immunoassay.

- Fasting and postprandial bioactive GLP-1 (7-36) levels were measured using a sandwich immunoassay.

- Fasting insulin and glucose levels were used to measure HOMA-IR using a formula,

HOMA-IR = Fasting insulin (mIU/L) X Fasting plasma glucose $(\mathrm{mM})$

$\%$ rise in insulin was calculated.

- To remove the effect of confounding factors of insulin resistance [34], Body Mass Index and waist Hip Ratio were calculated and compared.

\subsection{TCF-7L2 Polymorphism Screening}

DNA was extracted from buffy coat by spin column based Himedia HiPer ${ }^{\mathrm{TM}}$ gel extraction kit method. The extracted DNA was checked in $1 \%$ agarose gel with a high molecular weight ladder, quantitated based on absorbance at $260 \mathrm{~nm}$ and was used for Real Time PCR

- $20 \mathrm{mg}$ of genomic DNA will be amplified in each assay in the presence of specific probes for each SNP variant labelled with fluorescent dye at the 5' end and a quencher molecule at the $3^{\prime}$ end (designed by Applied Bio systems' "assays-by-design" service). Allele C was VIC labelled and T was FAM labelled

- PCR will be carried out in $1 \mu \mathrm{l}$ reaction volumes with $1 \times$ Absolute $^{\mathrm{TM}}$ PCR mix (ABgene) and $1 \times$ probe mix (Applied Bio systems).

- An initial denaturation at $95^{\circ} \mathrm{C}$ for 10 minutes to be followed by 40 cycles of PCR, with 15 seconds denaturation at $95^{\circ} \mathrm{C}$, and 1-minute annealing/extension at $60^{\circ} \mathrm{C}$.

- Following 40 cycles of PCR, fluorescence will be measured for each probe on a Pherastar plate reader and compared with an internal control ROX dye standard.

Figure 1. Shows the Extracted DNA Samples Run on 1\% Agarose Gel

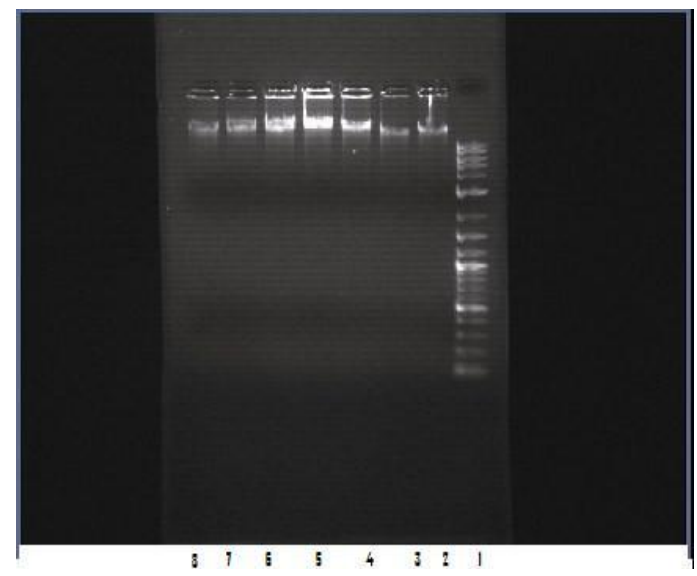

Figure1. Extracted DNA (Lane 2 To 8) Was Tested on 1\% Agarose Gel Using 1kb Ladder (Lane 1) Ladder Shows 10000, 8000, 7000, 6000, 5000, 4000, 3000, 2000 and 1000 Bp Fragments 
Figure 2. Shows Amplification Plot of a Batch of Samples.

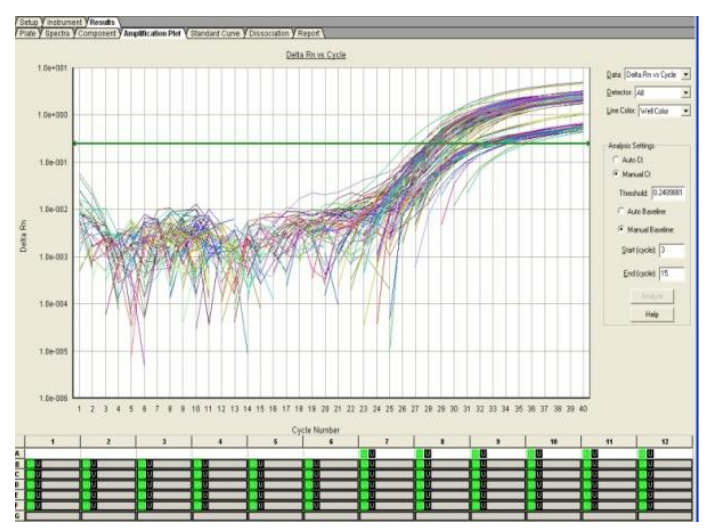

Figure2. Amplification plot of Real Time PCR

Figure 3 and Figure 4 Shows Allelic Discrimination Graph of Two Plates or Real Time Pcr

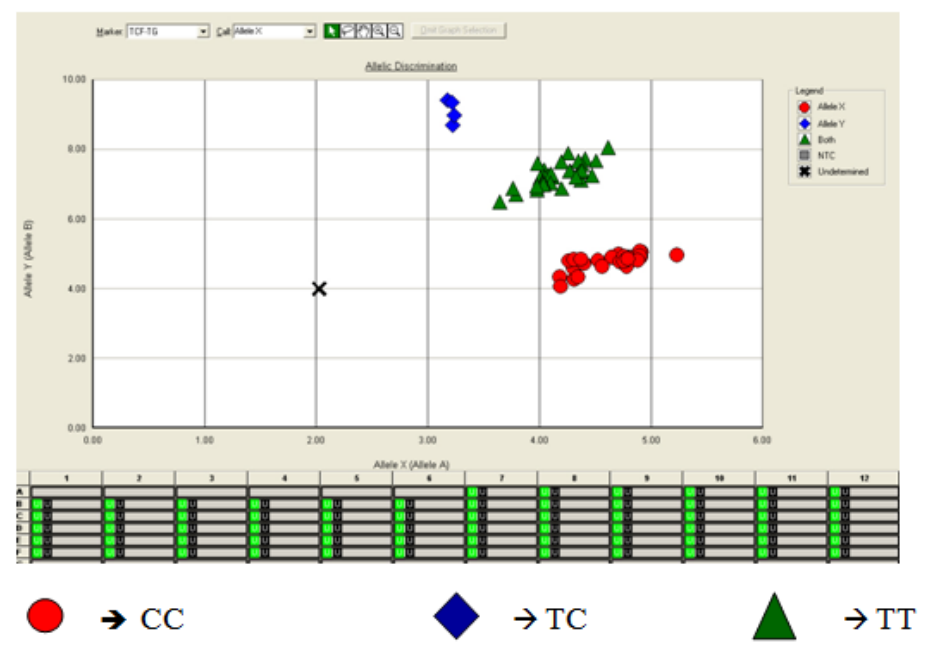

Figure3. Allelic Discrimination Graph of Real Time PCR - Plate 1

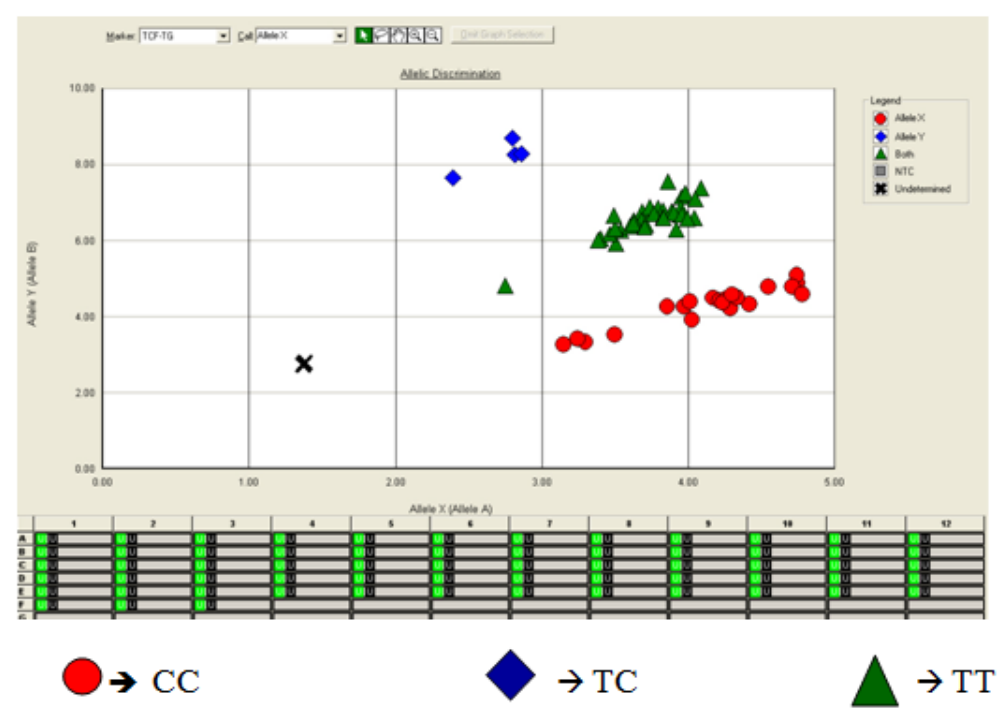

Figure4. Allelic Discrimination Graph of Real Time PCR - Plate 2

\subsection{Statistical Analysis}

1. Allele frequencies were calculated by allele counting.

2. Age, Waist Hip Ratio, BMI were compared between control subjects and patients by students t test. 
3. Genotype frequency distribution between cases and controls were compared with a Pearson's chisquare test for $2 * 3$ contingency table.

4. Fasting and postprandial glucose, insulin, GLP-1 levels were compared between control and cases by Student $t$ test. $\mathrm{p}<0.05$ was considered significant.

5. GLP-1 levels for both cases and controls were entered into a Microsoft Excel Spread Sheet. True positive and false positive rates for specific cut-off values were calculated. ROC curve was plotted and the area under the curve, 95\% confidence intervals SE were calculated using Accu ROC Software Version 2.4.

6. GLP-1 levels among the three genotypes were compared by Exact $\mathrm{F}$ test

7. Mean HOMA-IR, fasting insulin, postprandial insulin, percentage rise in insulin among the various genotypes were compared using ANOVA

8. Logistic regression analysis was performed to evaluate the interaction between TCF7L2 variation and Type 2 diabetes. Independent variables included in the analysis were age (quantitative), sex (male/female), BMI, WHR. The analysis was executed by SAS Statistical program Version 6.10 for Macintosh.

9. GLP-1 levels and HOMA-IR, fasting and postprandial insulin, Fasting and postprandial GLP-1, \% rise in insulin were correlated by Pearson's Correlation analysis.

3. RESULTS

- Table 1 shows Age, Sex, BMI, WHR, fasting and postprandial glucose, insulin and GLP-1 levels among patients and control subjects. Since all the confounding factors were matched there were no significant differences between the two groups. Significant differences could be observed with respect to fasting and postprandial glucose, insulin and GLP-1 levels

Table1. Characteristics of Patients with Type 2 Diabetes and of Control Subjects.

\begin{tabular}{|c|c|c|c|}
\hline Variables & Case & Control & P value \\
\hline Age & $54.02 \pm 9.276$ & $54.97 \pm 8.227$ & $\mathrm{p}=0.48$ \\
\hline Sex male & 52 & 52 & \multirow{2}{*}{$\mathrm{P}=1.0$} \\
\hline Female & 46 & 46 & $\mathrm{P}=0.72$ \\
\hline BMI & $25.2411 \pm 3.67$ & $25.04 \pm 2.93$ & $\mathrm{P}=0.68$ \\
\hline WHR & $0.9354 \pm 0.07$ & $0.9391 \pm 0.05$ & $\mathrm{P}=0.001$ \\
\hline Fasting Glucose (mg/dL) & $146 \pm 23$ & $86 \pm 14$ & $\mathrm{P}=0.001$ \\
\hline $\begin{array}{c}\text { Postprandial Glucose } \\
\text { (mg/dL) }\end{array}$ & $210 \pm 48$ & $127 \pm 29$ & \\
\hline Fasting Insulin (mIU/L) & $10.104 \pm 1.8879$ & $6.88 \pm 1.1$ & $\mathrm{P}=0.001$ \\
\hline Postprandial Insulin (mIU/L) & $20.364 \pm 1.967$ & $15.099 \pm 1.469$ & $\mathrm{P}=0.001$ \\
\hline Fasting GLP-1 (pM) & $24.186 \pm 2.208$ & $26.545 \pm 3.092$ & $\mathrm{P}=0.001$ \\
\hline Postprandial GLP-1 (pM) & $27.022 \pm 3.71$ & $41.801 \pm 29.35$ & $\mathrm{P}=0.001$ \\
\hline
\end{tabular}

- Table 2 shows Genotype distribution and Allele frequencies of human TCF7L2 gene in patients with Type 2 diabetes and control subjects. The Allele frequencies were $\mathrm{CC}=84, \mathrm{TC}=79$ and $\mathrm{TT}=$ 17. This was found to be in Hardy Weinberg equilibrium. Chi-square value is 3.84 , $\mathrm{P}$ value is .37 .

- Diabetic patients have significantly higher frequency of T+ genotype (TT and TC) than controls (.65 versus $.42 ; \mathrm{P}=.004)$.

- Even when the individual genotypes are considered, TT genotype is more common among cases than controls $(0.17$ versus $0.03, \mathrm{p}=.002)$ and $\mathrm{TC}$ genotype more common among cases than controls $(0.48$ versus $0.39, \mathrm{p}=0.002)$, whereas $\mathrm{CC}$ is more common among controls $(0.58$ versus $0.36, \mathrm{p}=0.002$ )

Table2. Genotype Distribution and Allele Frequencies of Human TCF7L2 Gene

\begin{tabular}{|c|c|c|c|}
\hline Genotype & Control & Case & P value \\
\hline TT & $2(2.8 \%)$ & $15(16.7 \%)$ & Chi sq $=12.15$ \\
$\mathrm{P}=0.002$ \\
\hline $\mathrm{TC}$ & $38(39.4 \%)$ & $43(47.8 \%)$ & \\
\hline $\mathrm{TC}+{ }^{*}$ & $52(57.7 \%)$ & $32(35.6 \%)$ & \multirow{2}{*}{ Chi $\mathrm{sq}=7.88$} \\
\hline $\mathrm{T}^{*}$ & $38(42.2 \%)$ & $58(64.5 \%)$ & $\mathrm{P}=.004$ \\
\hline
\end{tabular}

- $\mathrm{T}+\rightarrow \mathrm{TT}+\mathrm{TC} \& \mathrm{~T}-\rightarrow \mathrm{CC}$ 
- Table 3 shows the comparison of GLP-1 level among cases and controls. Significantly lower plasma fasting GLP-1 level $(24.19$ pM versus $26.55 \mathrm{pM}, \mathrm{P}<0.001)$ and postprandial GLP-1 levels (27.02 pM versus $41.8 \mathrm{pM}, \mathrm{P}<0.001$ ) is observed in Type 2 diabetic patients as compared to healthy controls

Table3. Comparison of Glp-1 Levels among Cases and Controls

\begin{tabular}{|c|c|c|c|}
\hline Variable & Case & Control & P value \\
\hline Fasting GLP-1 $(\mathrm{pM})$ & $24.19 \pm 2.21$ & $26.55 \pm 3.1$ & $\mathrm{t}=5.64, \mathrm{p}=0.001$ \\
\hline $\begin{array}{c}\text { Postprandial GLP-1 } \\
(\mathrm{pM})\end{array}$ & $27.02 \pm 3.1$ & $41.8 \pm 29.35$ & $\mathrm{t}=4.73, \mathrm{p}=0.001$ \\
\hline
\end{tabular}

- Table 4 shows the true positive and false positive rates for the various GLP-1 cut off values aimed at distinguishing cases from controls. Receiver Operating Characteristics curve analysis has detected the cut off value of GLP-1 as $27.8 \mathrm{pM}$ with a sensitivity of 0.789 and specificity 0 of 0.678

Table4. True Positive and False Positive Rates for Various Glp-1 Cut Off Values.

\begin{tabular}{|c|c|c|}
\hline GLP1 (pM) & Sensitivity & 1 - Specificity \\
\hline 25.000 & .958 & .700 \\
\hline 25.150 & .944 & .667 \\
\hline 25.250 & .944 & .644 \\
\hline 25.400 & .915 & .622 \\
\hline 25.650 & .915 & .600 \\
\hline 25.850 & .915 & .589 \\
\hline 25.950 & .915 & .578 \\
\hline 26.050 & .915 & .556 \\
\hline 26.125 & .915 & .522 \\
\hline 26.175 & .915 & .511 \\
\hline 26.250 & .915 & .500 \\
\hline 26.350 & .915 & .489 \\
\hline 26.420 & .915 & .467 \\
\hline 6.445 & .915 & .456 \\
\hline 26.455 & .915 & .444 \\
\hline 26.480 & .915 & .433 \\
\hline 26.650 & .915 & .389 \\
\hline 26.850 & .915 & .378 \\
\hline 26.950 & .859 & .356 \\
\hline 27.050 & .859 & .344 \\
\hline 27.200 & .845 & .344 \\
\hline 27.450 & .817 & .322 \\
\hline 27.850 & .789 & .322 \\
\hline
\end{tabular}

- Area under the ROC curve (Figure 5) is 0.576 (95\% CI is 0.546 to 0.606 )

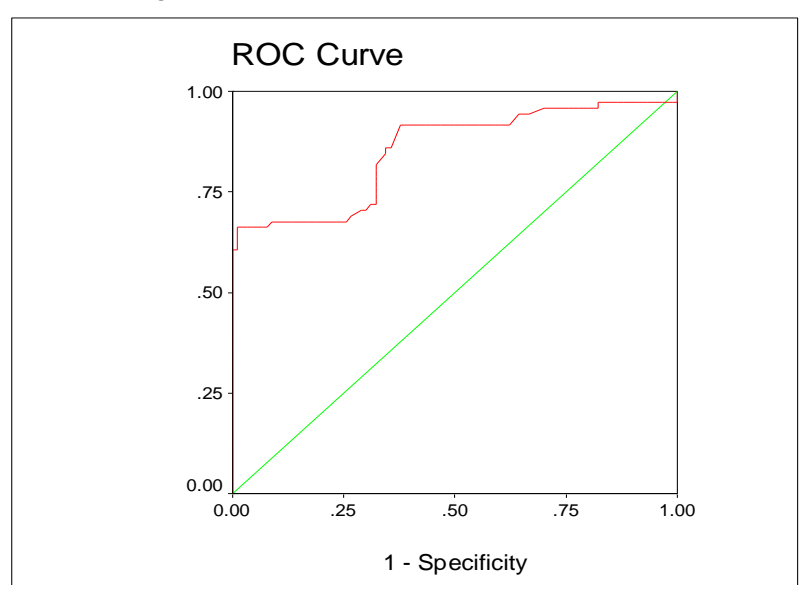

Figure5. Receiver Operating Characteristics Curve for Glp-1 as a Predictive Biomarker 
- Table 5 shows the difference in GLP-1 level between the various genotypes. The level was significantly lower among $\mathrm{T}+$ genotype individuals when compared to $\mathrm{T}$ - genotype individuals among both cases and controls

Table5. Correlation between Phenotype (Glp-1 Level) and Genotype.

\begin{tabular}{|c|c|c|c|c|c|}
\hline Group & Analyte & Genotype & Mean & Std. Deviation & $\begin{array}{c}\text { One way } \\
\text { ANOVA }\end{array}$ \\
\hline \multirow{3}{*}{ Case } & \multirow{2}{*}{ Fasting GLP1 (pM) } & $\mathrm{CC}$ & 26.147 & 1.5168 & $\mathrm{~F}=100.84$ \\
& & $\mathrm{TC}$ & 23.926 & 1.1431 & $\mathrm{P}=0.001$ \\
\cline { 3 - 5 } & & $\mathrm{TT}$ & 20.747 & .5780 & \\
\cline { 3 - 5 } & \multirow{2}{*}{ Postprandial GLP1(pM) } & $\mathrm{CC}$ & 30.738 & 2.5689 & $\mathrm{~F}=121.03$ \\
\cline { 3 - 5 } & & $\mathrm{TC}$ & 26.116 & 1.6422 & $\mathrm{P}=0.001$ \\
\cline { 3 - 5 } & & $\mathrm{TT}$ & 21.691 & .6666 & \\
\hline \multirow{3}{*}{ Control } & \multirow{2}{*}{ Fasting GLP1 (pM) } & $\mathrm{CC}$ & 28.363 & 1.8458 & $\mathrm{~F}=58.96$ \\
\cline { 3 - 5 } & & $\mathrm{TC}$ & 24.557 & 2.0049 & $\mathrm{P}=0.001$ \\
\cline { 3 - 5 } & & $\mathrm{TT}$ & 17.100 & .0000 & \\
\cline { 3 - 5 } & \multirow{2}{*}{ Postprandial GLP1 (pM) } & $\mathrm{CC}$ & 51.195 & 35.7734 & $\mathrm{~F}=5.76$ \\
\cline { 3 - 4 } & & $\mathrm{TC}$ & 29.661 & 3.7689 & $\mathrm{P}=0.001$ \\
\cline { 3 - 4 } & & $\mathrm{TT}$ & 19.200 & .1414 & \\
\hline
\end{tabular}

- Table 6 shows that among both cases and controls, HOMA-IR is high among T+ genotypic individuals when compared to $\mathrm{T}$ - individuals, postprandial insulin \% rise in insulin are low among $\mathrm{T}+$ genotypic individuals when compared to $\mathrm{T}$ - individuals.

Table6. Correlation between Genotype and Insulin Levels and Sensitivity.

\begin{tabular}{|c|c|c|c|c|c|}
\hline Group & Variable & Genotype & Mean & Std. Deviation & One way ANOVA \\
\hline \multirow[t]{9}{*}{ Case } & \multirow[t]{3}{*}{ HOMA - IR } & $\mathrm{CC}$ & 2.9963 & .25395 & \multirow{3}{*}{$\begin{array}{c}\mathrm{F}=208.41 \\
\mathrm{P}=0.001\end{array}$} \\
\hline & & $\mathrm{TC}$ & 4.1691 & .46898 & \\
\hline & & TT & 5.9825 & .75579 & \\
\hline & \multirow{3}{*}{$\begin{array}{c}\text { Post prandial } \\
\text { insulin (mIU/L) }\end{array}$} & $\mathrm{CC}$ & 21.816 & 1.1121 & \multirow{3}{*}{$\begin{array}{l}\mathrm{F}=74.70 \\
\mathrm{P}=0.001\end{array}$} \\
\hline & & $\mathrm{TC}$ & 20.388 & 1.2423 & \\
\hline & & TT & 17.200 & 1.2972 & \\
\hline & \multirow[t]{3}{*}{ \% Rise in insulin } & $\mathrm{CC}$ & 164.00 & 15.659 & \multirow{3}{*}{$\begin{array}{c}F=474.16 \\
P=0.001\end{array}$} \\
\hline & & $\mathrm{TC}$ & 97.30 & 12.943 & \\
\hline & & TT & 31.05 & 14.964 & \\
\hline \multirow[t]{9}{*}{ Control } & \multirow[t]{3}{*}{ HOMA - IR } & $\mathrm{CC}$ & 1.1915 & .14660 & \multirow{3}{*}{$\begin{array}{c}\mathrm{F}=125.16 \\
\mathrm{P}=0.001\end{array}$} \\
\hline & & $\mathrm{TC}$ & 1.6744 & .14569 & \\
\hline & & TT & 2.2377 & .05046 & \\
\hline & \multirow{3}{*}{$\begin{array}{c}\text { Post prandial } \\
\text { insulin (mIU/L) }\end{array}$} & AA & 15.622 & 1.5671 & \multirow{3}{*}{$\begin{array}{l}F=11.36 \\
\mathrm{P}=0.001\end{array}$} \\
\hline & & $\mathrm{AB}$ & 14.550 & .7739 & \\
\hline & & BB & 12.050 & .0707 & \\
\hline & \multirow[t]{3}{*}{ \% Rise in insulin } & AA & 154.84 & 33.890 & \multirow{3}{*}{$\begin{array}{l}\mathrm{F}=58.00 \\
\mathrm{P}=0.001\end{array}$} \\
\hline & & $\mathrm{AB}$ & 86.40 & 19.476 & \\
\hline & & BB & 31.00 & 2.782 & \\
\hline
\end{tabular}

- Table 7 shows the correlation between GLP-1 level on one hand and the insulin levels and HOMA - IR on the other hand. Negative correlation coefficient for HOMA -IR and Positive correlation coefficient for percentage rise in postprandial insulin indicates that high GLP-1 levels are associated with low HOMA-IR, high percentage rise in insulin

Table7. Correlation between Glp-1 Levels and Insulin Levels and Sensitivity

\begin{tabular}{|l|c|c|c|}
\hline \multicolumn{2}{|c|}{} & HOMA - IR & \% Rise in insulin \\
\hline \multirow{3}{*}{ Postprandial GLP1 } & Pearson Correlation & -.899 & .896 \\
\cline { 2 - 4 } & Sig. (2-tailed) & .000 & .000 \\
\cline { 2 - 4 } & $\mathbf{N}$ & 161 & 161 \\
\hline
\end{tabular}

- Table 8 shows the Odds ratio calculation on Univariate analysis to evaluate the risk of Type 2 diabetes among the various genotypes. Odds ratio is $2.0+0.4$.

- The age-, sex, BMI, WHR adjusted odds ratio between the genotypes for developing type 2 diabetes was $1.6(1.2-2.3)$ 
Table8. Univariate Analysis to Find Odds Ratio between Genotype and Type 2 Diabetes Susceptibility.

\begin{tabular}{|c|c|c|c|}
\hline GENOTYPE & CASES(n) & CONTROLS(n) & Pearson chisquare \\
\hline TT & 15 & 2 & $\chi 2=7.88 \mathrm{P}=0.005$ \\
TC & 43 & 36 & OR $=1.2$ to 2.3 \\
\hline CC & 32 & 52 & \\
\hline
\end{tabular}

\section{DISCUSSION}

Genetic factors in combination with several environmental risk factors are involved in the predisposition to Type 2 Diabetes mellitus. The susceptibility to Type 2 Diabetes is complex and recently significance is given to the role of incretins particularly GLP-1 in glycemic control, with the advent of therapeutics aimed at increasing GLP-1 levels, because GLP-1 is found to increase insulin release in response to food in the gut. Some studies have proven that GLP-1 increases insulin sensitivity ${ }^{[26][27][28]}$ but some studies defer the concept ${ }^{[25]}$. Another interesting aspect of GLP-1 synthesis is that it shares the same precursor as that of glucagon which is preproglucagon. Preproglucagon gets differentially processed in the two tissues to give rise to two different products GLP-1 in L cells of small intestine and glucagon in alpha cells of pancreas. This differential processing is explained by the tissue specific expression of enhancer TCF7L2 ${ }^{[22]}$ with a known polymorphic site in intron $6^{[32]}$. Normally, rs7903146 site is occupied by $\mathrm{C}$, if that is replaced by $\mathrm{T}$, it affects the posttranscriptional modification of TCF7L2 $\mathrm{mRNA}^{[33]}$. In view of this, a comprehensive case control study was performed in South Indians to address three questions.

- Is TCF7L2 gene polymorphism the cause for differences in the Type 2 diabetic susceptibility among any population?

- If so, does it involve alteration in GLP-1 levels and thereby postprandial insulin secretion alone or does it have a role in altering insulin sensitivity as well?

- If so, can a cut off value be set for GLP-1 levels, below which significant diabetes risk be assessed?

The three TCF7L2 genotypes were assessed among 90 newly diagnosed cases of Type 2 diabetes and 90 age and sex matched healthy volunteers. The evidence available showed that there is a significantly higher proportion of TT and TC genotypic individuals among cases when compared to controls suggesting us that $\mathrm{T}$ allele can increase the susceptibility to Type 2 diabetes.

To analyse, the phenotypic effect of this polymorphism, we analysed fasting and postprandial GLP-1 levels among the various genotypes. The mean GLP 1 activity among $\mathrm{T}+$ genotypic individuals is lower than individuals with T- genotype, suggesting us that $\mathrm{T}$ polymorphism affects the GLP- 1 levels. Simultaneously, to re-establish the fact that GLP-1 decrease can result in Type 2 diabetes, we compared GLP-1 levels among cases and controls, and we found GLP-1 level to be low among cases than among controls. So, the conclusion is TCF7L2 gene variation by altering the post transcriptional modification of preproglucagon gene, decreases GLP-1 levels and that increases the risk of Type 2 diabetes.

We measured fasting and postprandial insulin, calculated HOMA- IR, as an index of insulin sensitivity. We found that postprandial insulin levels were low and HOMA index was high among cases when compared to controls, proving the fact that Type 2 diabetes is characterised by not only insulin resistance but also an insulin secretory defect.

To identify the role of GLP-1 in glycemic control, we correlated GLP-1 levels with HOMA-IR, postprandial insulin and percentage rise in insulin. A positive correlation coefficient with a significant $\mathrm{p}$ value for \% rise in postprandial insulin suggests that decrease in GLP-1 level causes a decrease in insulin secretion. A negative correlation coefficient with a significant $p$ value for HOMA-IR suggests that decrease in GLP-1 level causes an increase in HOMA-IR or an increase in insulin resistance. Thus, GLP-1 has got a role in both insulin secretion and in sensitising the cells to insulin activity.

When an attempt was made to set up a cut off value, Receiver Operating Characteristics curve analysis has detected the cut off value of GLP-1 as $27.8 \mathrm{pM}$ with a sensitivity of 0.789 and specificity Of 0.678 Thus, Genotypes TT and TC cause a decrease in fasting and postprandial GLP-1 levels, which in turn by decreasing insulin levels and by increasing insulin resistance increase the risk of Type 2 diabetes. 


\section{CONCLUSION}

In conclusion, we have examined the association of the TCF7L2 genotypes and phenotypes with Type 2 diabetes and have found a significant association of T variant and low GLP-1 level among Type 2 diabetic individuals

- Thus, the low GLP-1 levels and the T genotype may be an independent risk factor for Type 2 diabetes.

- GLP-1 level can be used as a parameter for assessing Type 2 diabetes risk.

- TCF7L2 genotype polymorphism detection and GLP-1 levels measurement can be used to customise treatment of Type 2 diabetes with gliptins which increase GLP-1 levels by inhibiting Dipeptidyl Peptidase IV, an enzyme which metabolises GLP-1.

\section{REFERENCES}

[1] McCarthy MI, Froguel P. Genetic approaches to the molecular understanding of type 2 diabetes. Am J Physiol Endocrinol Metab 2002; 283:217-225, Frayling TM.

[2] Genome-wide association studies provide new insights into type 2 diabetes aetiology. Nat Rev Genet 2007;8:657-662

[3] The inherited basis of diabetes mellitus: implications for the genetic analysis of complex traits. Annu Rev Genomics Hum Genet 2003;4:257-91

[4] Keenan HA, Costacou T, Sun JK, Doria A, Cavellerano J, Coney J, Orchard TJ, Aiello LP, King GL: Clinical factors associated with resistance to micro vascular complications in diabetic patients of extreme disease duration: the 50-year medalist study. Diabetes Care30 : 1995-1997,2007

[5] Boyle PJ: Diabetes mellitus and macro vascular disease: mechanisms and mediators. Am J Med 120: S12S17,2007

[6] Creutzfeldt W, Nauck M. Gut hormones and diabetes mellitus. Diabetes Metab Rev 8: 149-177, 1992.

[7] D'Alessio DA. Incretins: glucose-dependent insulinotropic polypeptide and Glucagon-like peptide 1. In: Ellenberg \& Rifkins's Diabetes Mellitus, edited by Porte JD, Sherwin RS, and Baron A. New York: McGraw-Hill, 2002, p. 85-96.

[8] Göke R, Fehmann H-C, Linn T, Schmidt H, Krause M, Eng J, and Göke B (1993) Exendin-4 is a high potency agonist and truncated exendin-(9-39)-amide an antagonist at the glucagon-like peptide 1-(7-36)amide receptor of insulin secreting $\beta$-cells. J Biol Chem 268: 19650-19655.

[9] Kieffer TJ, Habener JF. The glucagon-like peptides. Endocr Rev 20: 876-913, 1999. Nathan DM, Schreiber E, Fogel H, Mojsov S, Habener JF: Insulinotropic action of glucagon-like peptide-I-(7-37) in diabetic and non-diabetic subjects. Diabetes Care 15:270-276, 1992

[10] Gutniak M, Orskov C, Holst JJ, Ahrén B, Efendic S: Antidiabetogenic effect of glucagon-like peptide-1 (7-36) amide in normal subjects and patients with diabetes mellitus. N Engl J Med 326:1316-1322, 1992

[11] Komatsu R, Matsuyama T, Namba M, Watanabe N, Itoh H, Kono N, Tarui S: Glucagonostatic and insulinotropic action of glucagon like peptide I-(7-36)- amide. D i a b e t e s 38:902-905, 1989

[12] Ritzel R, Orskov C, Holst JJ, Nauck MA: Pharmacokinetic, insulinotropic, and glucagon static properties of GLP-1 [7-36 amide] after subcutaneous injection in healthy volunteers: dose-response-relationships. D i a b e to lo g i a 38:720-725, 1995

[13] Wettergren A, Schjoldager B, Mortensen PE, Myhre J, Christiansen J, Holst JJ Truncated GLP-1 (proglucagon 78-107-amide) inhibits gastric and pancreatic functions in man. Dig Dis Sci 38:665-673, 1993

[14] D'alessio DA, Kahn SE, Leusner CR, Ensinck JW: Glucagon-like peptide 1enhances glucose tolerance both by stimulation of insulin release and by increasing insulin-independent glucose disposal. J Clin Invest $93: 2263-2266,1994$

[15] D'alessio DA, Prigeon RL, Ensinck JW: Enteral enhancement of glucose disposition by both insulindependent and insulin-independent processes: a physiological role of glucagon-like peptide I. D i a b e t e s 44:1433-1437, 1995

[16] Morales M, Lopez-Delgado MI, Alcantara A, Luque MA, Clemente F, Marquez L, Puente J, Vinambres C, Malaisse WJ, Villanueva-Penacarrillo ML, Va 1 v e $\mathrm{r}$ d e I: Preserved GLP-1 effects on glycogen synthase a activity and glucose metabolism in isolated hepatocytes and skeletal muscle from diabetic rats. Diabetes 46:1264-1269, 1997

[17] Montrose-Rafizadeh, C., Yang, H., Rodgers, B. D., Beday, A., Pritchette, L. A., TCF-4 mediates cell type-specific regulation of proglucagon gene expression by beta-cateninand Eng. J. (1997) J. Biol. Chem. $272,21201-21206$

[18] Thiele, T. E., Seeley, R. J., D’Alessio, D., Eng, J., Bernstein, I. L., Woods, S. C., and van Dijk. G. (1998) Brain Res. 801, 164-170 
[19] Seeley, R. J., Blake, K., Rushing, P. A., Benoit, S., Eng, J., Woods. S. C., and D’Alessio, D. (2000). A metanalysis of studies on TCF7L2J. Neurosci. 20, 1616- 1621

[20] Yi F, Brubaker PL, Jin T: TCF-4 mediates cell type-specific regulation of proglucagon gene expression by beta-catenin and glycogen synthase kinase-3beta. J Biol Chem 280:1457-1464.

[21] Brubaker, P. L., Schloos, J., and Drucker, D. J. (1998) Review on TCF7L2 Endocrinology 139, 41084114

[22] Fenghua Yi, Patricia L.Brubaker and Tianru Jin, TCF4 mediates cell specific regulation of proglucagon gene expression by $\beta$ catenin and glycogen synthase kinase-3 $\beta$

[23] Grant SF, Thorleifsson G, Reynisdottir I, Benediktsson R, Manolescu A, Sainz J, Helgason A, Stefansson H, Emilsson V, Helgadottir A, Styrkarsdottir U, Magnusson KP, Walters GB, Palsdottir E, Jonsdottir T, Gudmundsdottir T, Gylfason A, Saemundsdottir J, Wilensky RL, Reilly MP, Rader DJ, Bagger Y, Christiansen C, Gudnason V, Sigurdsson G, Thorsteinsdottir U, Gulcher JR, Kong A, Stefansson K: Variant of transcription factor 7-like 2 (TCF7L2) gene confers risk of type 2 diabetes. Nat Genet 38:320323, 2006

[24] Florez JC, Jablonski KA, Bayley N, Pollin TI, de Bakker PI, Shuldiner AR, Knowler WC, Nathan DM, Altshuler D, Diabetes Prevention Program Research Group. TCF7L2 polymorphisms and progression to diabetes in the Diabetes Prevention Program. N Engl J Med 2006;355:241-250

[25] Saxena R, Gianniny L, Burtt NP, Lyssenko V, Giuducci C, Sjo“ gren M, Florez JC, Almgren P, Isomaa B, Orho-Melander M, Lindblad U, Daly MJ, Tuomi T, Hirschhorn JN, Ardlie KG, Groop LC, Altshuler D. Common single nucleotide polymorphisms in TCF7L2 are reproducibly associated with type 2 diabetes and reduce the insulin response to glucose in nondiabetic individuals. Diabetes 2006;55:2890-2895

[26] Damcott CM, Pollin TI, Reinhart LJ, Ott SH, Shen H, Silver KD, Mitchell BD, Shuldiner AR. Polymorphisms in the transcription factor 7-like 2 (TCF7L2) gene are associated with type 2 diabetes in the Amish: replication and evidence for a role in both insulin secretion and insulin resistance. Diabetes 2006;55:2654-2659

[27] Lyssenko V, Lupi R, Marchetti P, Del Guerra S, Orho-Melander M, AlmgrenP, Sjo“ gren M, Ling C, Eriksson KF, Lethagen AL, Mancarella R, Berglund G,Tuomi T, Nilsson P, Del Prato S, Groop L. Mechanisms by which commonvariants in the TCF7L2 gene increase risk of type 2 diabetes. J Clin Invest2007; 117:2155-2163

[28] Pilgaard K, Jensen CB, Schou JH, Lyssenko V, Wegner L, Brøns C, Vilsbøll T, Hansen T, Madsbad S, Holst JJ, Vølund A, Poulsen P, Groop L, Pedersen O, Vaag AA. The T allele of rs7903146 TCF7L2 is associated with impaired insulinotropic action of incretin hormones, reduced $24 \mathrm{~h}$ profiles of plasma insulin and glucagon, and increased hepatic glucose production in young healthy men. Diabetologia 2009;52:1298-1307

[29] Wegner L, Hussain MS, Pilgaard K, Hansen T, Pedersen O, Vaag A, Poulsen P. Impact of TCF7L2 rs7903146 on insulin secretion and action in young and elderly Danish twins. J Clin Endocrinol Metab 2008;93:4013-4019

[30] Scha“ fer SA, Tschritter O, Machicao F, Thamer C, Stefan N, Gallwitz B, Holst JJ, Dekker JM, 't Hart LM, Nijpels G, van Haeften TW, Ha“ ring HU, Fritsche A. Impaired glucagon-like peptide-1-induced insulin secretion in carriers of transcription factor 7-like 2 (TCF7L2) gene polymorphisms. Diabetologia 2007;50:2443-2450

[31] Diabetes Care January 2006 vol. 29 no. suppl 1 s43-s48

[32] Ganesh Chouhan, Charles j spurgeon, Rubina Tabassum, Seema Bhaskar, Smita Kulkarni, Impact of common variants of TCF7L2 on the risk of Type 2 diabetes in 5,614 Indians. Diabetes vol.59, August 2010.

[33] Lauren Gianniny, Noel P Brutt, Valeria, Lissenko, Candice Giuducci. Common single nucleotide polymorphism in TCF7L2 are reproducibly associated with type 2 diabetes and reduces insulin response to glucose in diabetic individuals. Diabetes, vol55, October 2006

Citation: Dr. Shanmugapriya Chandrasekaran," TCF 712 Gene Variant Rs 7903146 Affects the Risk of Type 2 Diabetes by Modulating Incretin Secretion", International Journal of Clinical Chemistry and Laboratory Medicine (IJCCLM), vol. 5, no. 1, pp. 7-16, 2019.http://dx.doi.org/10. 20431/2455-7153.0501002

Copyright: (C) 2019 Authors. This is an open-access article distributed under the terms of the Creative Commons Attribution License, which permits unrestricted use, distribution, and reproduction in any medium, provided the original author and source are credited. 